\title{
BIOPRECIPITATION OF ARSENIC SULPHIDE AT LOW PH
}

\author{
F. BATTAGLIA-BRUNET ${ }^{1}$, D. MORIN ${ }^{1}$, S. COULON $^{1}$, A. BURNOL ${ }^{1}$, \\ A. C. SCHEINOST ${ }^{2}$ and C. JOULIAN ${ }^{1}$ \\ ${ }^{1}$ BRGM, Environment \& Process Division, 3, av. Claude Guillemin, 45060 Orléans cedex 02, \\ France; E-mail: f.battaglia@brgm.fr; d.morin@brgm.fr \\ ${ }^{2}$ ESRF, Rossendorf Beamline, B.P. 220, F-38043 Grenoble
}

\begin{abstract}
A process for the precipitation of trivalent arsenic sulphide in sulphate-reducing condition at low $\mathrm{pH}$ would be very attractive due to the high arsenic content (60\%) in the final precipitate. A bacterial consortium able to reduce sulphate at $\mathrm{pH} 4.5$ served to inoculate a column bioreactor that was continuously fed with As(V) or As(III), glycerol as energy source, at $\mathrm{pH}$ values between 2 and 5 . The best efficiency, in terms of residual As concentration in the outlet, was obtained with the lowest feed $\mathrm{pH}$, i.e. $\mathrm{pH}$ 2. However, in these conditions, the bacterial activity inside the bioreactor was isolated in higher $\mathrm{pH}$ zones. The diversity, functionality and evolution of the consortium colonizing the bioreactor were characterized by means of biomolecular tools, in relation with operating parameters ( $\mathrm{pH}$, As, sulphide). Fermentative and sulphate-reducing bacteria were present both in the liquid phase and onto the filling material. All sulphate-reducers that were detected belonged to the Desulfosporosinus genus. Spectroscopic analyses of the solid phases that precipitated into the bioreactor revealed the presence of amorphous precursors of orpiment of nano-size.
\end{abstract}

\section{INTRODUCTION}

The mining and metallurgy effluents may contain high concentrations of many metals and metalloids (Fe, $\mathrm{Al}, \mathrm{Cu}, \mathrm{Zn}$,

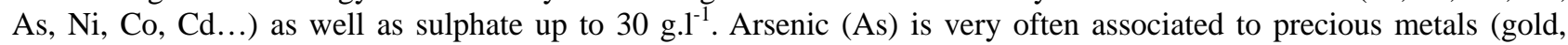
silver) in refractory sulphide ores that are submitted to bioleaching (Adam, 1997). A typical bioleach liquor from gold ore treatment, at $\mathrm{pH}$ close to 1 , contains $13 \mathrm{~g} \mathrm{l}^{-1}$ As and $25 \mathrm{~g} \mathrm{l}^{-1} \mathrm{Fe}$ (Grossin, 1994). In most cases the treatment of these effluents consists of lime neutralization. Sulphate is removed as gypsum, arsenic co-precipitates with iron hydroxides, and the other metals precipitate as hydroxides. This method is simple but produces voluminous quantities of hazardous waste that have no value (Zinck, 1997). For about ten years, several private or public organisms have contributed to the development of technologies sharing a common principle based on the precipitation of metallic sulphides by biologically produced $\mathrm{H}_{2} \mathrm{~S}$ using sulphate-reducing bacteria (SRB). SRB use sulphate as a terminal electron acceptor, $\mathrm{SO}_{4}{ }^{2-}$ being converted into $\mathrm{H}_{2} \mathrm{~S}$. A bio-process using SRB for the selective precipitation of arsenic as trivalent arsenic sulphide would be very attractive, as the final solid waste may contain up to $60 \%$ As in weight. However, this processing way has not been well documented because As(III) sulphide is known to precipitate mainly in acidic conditions as amorphous or crystallized orpiment $\mathrm{As}_{2} \mathrm{~S}_{3}$ and SRB have been considered for years as being sensitive to acidity. However, recent work showed that sulphate-reducing processes may be efficient in acidophilic conditions, using the appropriate substrate and operating conditions (Kimura et al., 2006). The present report describes the development of a biological system for the precipitation of arsenic sulphide at small bioreactor scale. The composition of the bacterial population involved in this process was determined, and its evolution according to the changes in operating conditions was monitored by molecular fingerprinting of the community structure. The solids phases precipitated into the bioreactor were characterised by spectroscopy.

\section{MATERIAL AND METHODS}

The fixed-film bioreactors consisted in glass columns (320 mm height, $35 \mathrm{~mm}$ inner diameter) equipped with water jackets for temperature regulation and filled with 2-5 mm pozzolana pieces. The working volume was $325 \mathrm{ml}$. Media used in this experiment were sterilised by autoclaving $\left(120^{\circ} \mathrm{C}, 30 \mathrm{~min}\right)$ and de-oxygenated by sterile $\mathrm{N}_{2}$ bubbling. The inoculum was a mixed bacterial population enriched from acidic sediments sampled from a mining site and able to reduce sulphate at $\mathrm{pH}$ 4.5. The basal medium contained the following ingredients, per litre: $\mathrm{K}_{2} \mathrm{HPO}_{4}, 0.5 \mathrm{~g} ; \mathrm{NH}_{4} \mathrm{Cl}, 2 \mathrm{~g}$ ; $\mathrm{Na}_{2} \mathrm{SO}_{4}, 1.4 \mathrm{~g}$; $\mathrm{MgSO}_{4} .7 \mathrm{H}_{2} \mathrm{O}, 2 \mathrm{~g}$; glycerol, $0.5 \mathrm{~g}$; yeast extract, $1 \mathrm{~g}$; trace elements solution (EDTA, $3 \mathrm{~g}$; FeSO .7 $\mathrm{H}_{2} \mathrm{O}, 1.1 \mathrm{~g} ; \mathrm{MnSO}_{4}, 65 \mathrm{mg} ; \mathrm{ZnSO}_{4}, 89 \mathrm{mg} ; \mathrm{NiCl}_{2}, 24 \mathrm{mg} ; \mathrm{Na}_{2} \mathrm{MoO}_{4} .2 \mathrm{H}_{2} \mathrm{O}, 18 \mathrm{mg} ; \mathrm{H}_{3} \mathrm{BO}_{3}, 0.3 \mathrm{~g} ; \mathrm{CuCl}_{2}, 2 \mathrm{mg}$ and $\left.\mathrm{CoSO}_{4} .7 \mathrm{H}_{2} \mathrm{O}, 130 \mathrm{mg}\right), 1 \mathrm{ml}$. $\mathrm{pH}$ was adjusted to 4.2. At the beginning of the experiment, the basal medium was supplemented with $5 \mathrm{mM} \mathrm{ZnSO}_{4}$ and $1.33 \mathrm{mM} \mathrm{As}(\mathrm{V}) .400 \mathrm{ml}$ of this medium were inoculated with $40 \mathrm{ml}$ of the bacterial consortium and up-flow injected into the bioreactor using a peristaltic pump (Ismatec IPC). The $440 \mathrm{ml}$ bacterial suspension up-flow circulated through the pozzolana bed during 1 hour. Then, the circulation was stopped and the system worked in fed-batch conditions during 1 month. The temperature was maintained at $30^{\circ} \mathrm{C}$. The fed-batch medium was identical to the inoculation medium. Every day, $10 \mathrm{ml}$ of fresh medium were up-flow injected and $10 \mathrm{ml}$ were sampled at the outflow for analyses. One month after inoculation, the reactor was continuously up-flow fed. The 
feeding medium was identical to the fed-batch medium, except for $\mathrm{ZnSO}_{4}$ that was omitted and for the $\mathrm{pH}$ that was adjusted to 4.4. Sterile $\mathrm{N}_{2}$ was injected in the outflow flask. The composition of the medium was changed during the continuous experiment. Glycerol concentration was increased in order to determine if the sulphate reduction was limited by the energy source available. Nitrogen availability was reduced in two modified basal media (MM1 and MM2): MM1 contained less $\mathrm{NH}_{4} \mathrm{Cl}(1 \mathrm{~g})$ and less yeast extract $(0.5 \mathrm{~g})$ than the enrichment medium ; MM2 was identical to MM1 except that yeast extract concentration was increased to $0.75 \mathrm{~g} \mathrm{l}^{-1}$. The chronology of the different operating conditions that were tested is given in Table 1.

Table1. Bioreactor C1, changes in operating conditions. Changes in bold.

\begin{tabular}{|c|c|c|c|c|}
\hline Age & Feed pH & As form & Glycerol in feed & Basal medium \\
\hline 41 & 4.4 & $\mathrm{As}(\mathrm{V})$ & 0.5 g. $^{-1}$ & enrichment \\
\hline 70 & 4.4 & $\mathrm{As}(\mathrm{V})$ & 1 g. $^{-1}$ & enrichment \\
\hline 101 & 4.4 & $\mathrm{As}(\mathrm{V})$ & 1.5 g.l $^{-1}$ & enrichment \\
\hline 141 & 4.4 & $\mathrm{As}(\mathrm{V})$ & $1.5{\mathrm{~g} . \mathrm{l}^{-1}}^{-1}$ & MM1 \\
\hline 184 & 4.4 & $\mathrm{As}(\mathrm{V})$ & $1.5 \mathrm{g.l}^{-1}$ & MM2 \\
\hline 254 & 4.4 & As(III) & $1.5{\mathrm{~g} . \mathrm{l}^{-1}}^{-1}$ & MM2 \\
\hline 302 & 3.4 & As(III) & $1.5{\mathrm{~g} . \mathrm{l}^{-1}}^{-1}$ & MM2 \\
\hline 328 & 2.8 & As(III) & 1.5 g.t $^{-1}$ & MM2 \\
\hline 354 & 2.0 & As(III) & $1.5{\mathrm{~g} . \mathrm{l}^{-1}}^{-1}$ & MM2 \\
\hline 541 & 2.0 & As(V) & $1.5{\mathrm{~g} . \mathrm{l}^{-1}}^{-1}$ & MM2 \\
\hline
\end{tabular}

Every day, the outflow was sampled for the determination of $\mathrm{pH}$, redox potential, As(V), total As, and sulphate. The feeding medium was also analysed for As(V), total As and sulphate. The following analyses were performed at irregular time intervals: population structure (CE-SSCP fingerprints), direct counts (optical microscope and Thoma cell, x 400 magnification), acetate. Total arsenic was analysed by Atomic Absorption Spectrophotometry (AAS) (Varian SpectAA 220FS) with standards prepared in $1 \% \mathrm{HCl}(\mathrm{v} / \mathrm{v})$. As(V) and As(III) were separated by extracting As(III) in methyl isobutyl ketone with pyrrolidine dithiocarbamate (Battaglia-Brunet et al., 2002). As(V) remaining in the aqueous phase was analysed by AAS (Varian SpectrAA 300), using As(V) standards prepared by following the same extraction method. pH and redox potential (Ag/AgCl) were measured using a Heitolab MPC 350 multiparameter system equipped with Heito combined electrodes. Sulphate was quantified using the kit Merck Spectroquant ${ }^{\circledR} 1.14548 .001$ (detection limit 5 mg.l-1). Zinc was analysed by AAS (Varian SpectrAA 300). Samples of solids from the bioreactor were dried under N2 for analysis by X-ray Absorption Near Edge Structure (XANES) Spectroscopy and Extended X-ray Absorption Fine Structure (EXAFS) Spectroscopy. Arsenic K-edge EXAFS data for biogenic samples and selected references were recorded at the European Synchrotron Radiation Facility (ESRF).).

At the end of the experiment, the filling material was carefully removed from the column; $5 \mathrm{~cm}$ thick portions were recovered. In each portion, $\mathrm{pH}$ was measured, and samples of solids and liquids were taken. For direct population counts, 3 to 4 grams of pozzolana (exact mass was recorded) were put into a sterile tube then carefully rinsed with 10 $\mathrm{ml}$ of 9 g.l-1 $\mathrm{NaCl}$ sterile solution. The rinse water was thrown away and replaced by $10 \mathrm{ml}$ fresh solution, and the tube was vortex agitated for $1 \mathrm{~min}$. The resulting liquid was used for direct counting and structure analyses of the fixed bacterial population.

For biomolecular monitoring, genomic DNA was extracted using the FastPrep DNA Spin Kit for Soil (Bio101) from cells pellet obtained by centrifuging $2 \mathrm{ml}$ of liquid taken at the bottom, the top, and from the outflow of the column during the course of the experiment, as well as from the biofilm colonizing the filling material sampled when dismantling the column. The structure of the population and its evolution with time was visualized by CE-SSCP on 16S rRNA genes V3 region amplified with the universal bacterial primers w34, 5'-end labeled with the fluorescent dye FAM, and w49 (d'Hugues et al., 2008). Raw data analyses and assignment of peak position were done with the software GeneScan (Applied Biosystem). Bacterial species colonizing the column were identified based on retrieved 16S rRNA gene sequences. These genes were amplified with the universal bacterial primerset 8F/1406R (d'Hugues et al., 2008), and ligated into pCR-TA-TOPO plasmids (Invitrogen). Clones carrying unique inserts were screened by CE-SSCP. The insert of selected clones were sequenced by Cogenics using plasmid specific primers. Consensus nucleotide sequences were submitted to a blast search (www3.ncbi.nlm.nih.gov/BLAST) for identification of closest bacterial relatives. In order to assign a 16S rRNA gene sequence to each peak detected on the community fingerprints, selected 16S rRNA gene clones were also analysed individually by CE-SSCP and positioned on the community profiles. 


\section{RESULTS AND DISCUSSION}

\section{Continuous Condition at PHh 4.4 with $\operatorname{As}(\mathrm{V})$}

The bioreactor was continuously fed at $\mathrm{pH} 4.4$ with $\mathrm{As}(\mathrm{V})$ during the 250 first days of experiment. As soon as the continuous feed started, the sulphate concentration was very similar in the feed and outlet samples, showing that almost no reduction of sulphate occurred into the column. Arsenic concentration decreased down to $4 \mathrm{mg}^{-\mathrm{l}^{-1}}$, and then increased

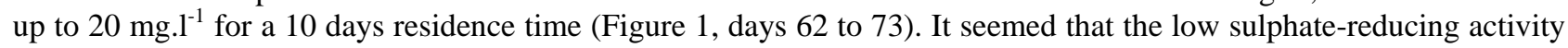
limited the As precipitation efficiency. In order to determine if the sulphate-reducing activity was limited by energetic substrate availability, the glycerol concentration was increased. The doubling of glycerol concentration in the feed medium had a dramatic but transient effect on the sulphate-reducing activity. The sulphate concentration in the outlet decreased from 1500 to $600 \mathrm{mg.l}^{-1}$ in 5 days, i.e. 1/2 residence time. After this event, the outlet sulphate concentration increased again from 700 to $1400 \mathrm{mg}^{-1} \mathrm{l}^{-1}$, then stayed relatively constant for 1 residence time. These results suggest that the sulphate-reducing activity was actually limited by energetic substrate availability. However, the rough increase of sulphate-reducing activity probably induced a peak of dissolved $\mathrm{H}_{2} \mathrm{~S}$ that was toxic to the cells working at low $\mathrm{pH}$.

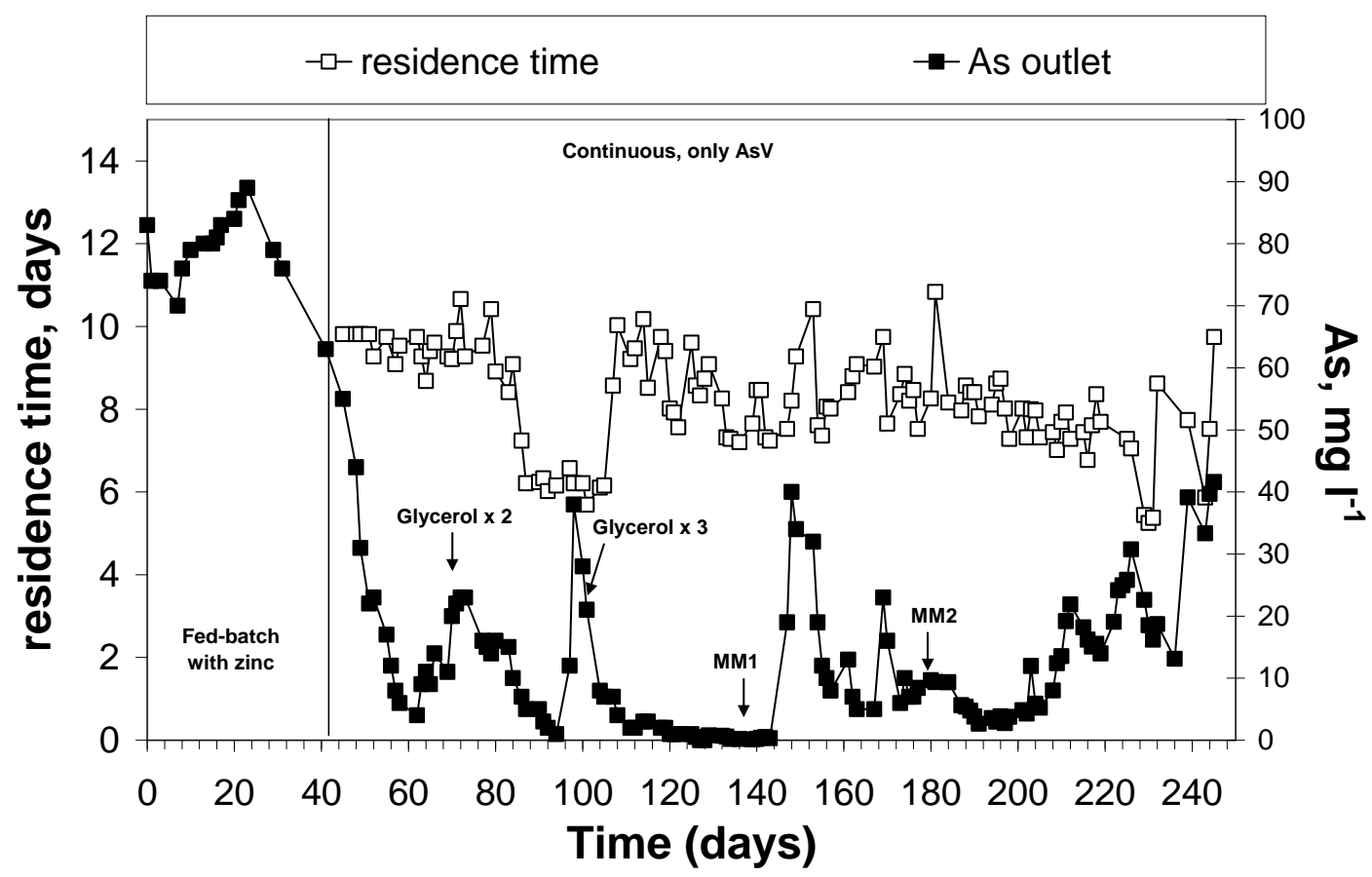

Figure 1. Evolution of arsenic concentration in the outlet of the bioreactor and residence time during the first 250 days

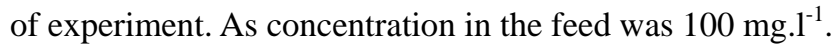

In order to reduce the negative impact of $\mathrm{H}_{2} \mathrm{~S}$ and acetate accumulation into the column, the residence time was decreased (day 87) from 10 to 6 days. This change induced a peak of As in the outlet (day 97). Thus, the residence time was increased again to 10 days, and the glycerol concentration in the feed medium fixed to $1.5 \mathrm{~g} \mathrm{l}^{-1}$. During the following period, arsenic concentration in the outlet decreased again and remained lower than 1 mg. l $^{-1}$ during 20 days (days 120 to 140). Whereas the As removal efficiency was satisfactory, the sulphate concentration in the outlet was nearly equivalent to the sulphate concentration in the feed. It was supposed that a reaction possibly promoted the oxidation of some excess sulphide into sulphate in the outlet flask. Nitrogen was provided in high concentration in the enrichment medium: 0.7 g. $l^{-1}$ ammonium as ammonium chloride and 1 g. $1^{-1}$ yeast extract. The introduction of MM1 medium, containing 50\% less ammonium and yeast extract than the enrichment medium, had an immediate negative effect on arsenic removal (day 143). A dramatic increase of sulphate concentration in the outlet (up to $2500 \mathrm{mg}^{-1}{ }^{-1}$ ) was observed simultaneously to the peak of arsenic. This event showed that the high sulphate concentration in the outlet was not linked to sulphide re-oxidation, but certainly to evaporation. The evaporation level was controlled, comparing the pump flow-rate to the mass of liquid recovered in the outlet flask. It was found that the evaporation level was around $10 \%$ per day. Thus, when the sulphate concentration was equivalent in the feed and outlet, $10 \%$ of the inlet sulphate had been reduced. For example, As was entirely removed at day 128; sulphate concentration was 1780 mg.l $\mathrm{l}^{-1}$ in the feed and $1700 \mathrm{mg} . \mathrm{l}^{-1}$ in the outlet. In fact, $230 \mathrm{mg} . \mathrm{l}^{-1}$ sulphate had actually been reduced. The theory indicates that, in order to precipitate $100 \mathrm{mg}^{-l^{-1}} \mathrm{As}(1.33 \mathrm{mM})$ in the $\mathrm{As}_{2} \mathrm{~S}_{3}$ form, at least $192 \mathrm{mg} . \mathrm{l}^{-1}$ sulphate $(2 \mathrm{mM})$ should be reduced. As a fact, during the period from day 120 to day 140 when As was efficiently removed from the solution, just the quantity of $\mathrm{H}_{2} \mathrm{~S}$ necessary to precipitate all arsenic was produced. This result is consistent with the chemical information given in literature, saying that arsenic sulphide should precipitate when $\mathrm{H}_{2} \mathrm{~S}$ is not in excess (Wilkin et al., 2003). Ten days after MM1 introduction, the system seemed to adapt itself to the modified medium, as As concentration decreased in the 
outlet, however the bioreactor was less efficient than with the enrichment medium. The MM2 medium, containing more

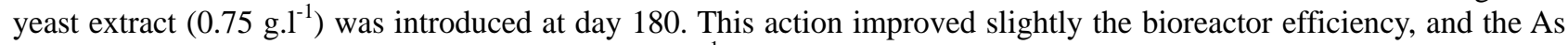
concentration in the outlet decreased down to $3 \mathrm{mg} . \mathrm{l}^{-1}$. Then, the residence time was decreased but more progressively than the first time. In spite of this precaution, the As concentration increased again in the outlet.

\section{Influence of As(Iii) and Feed Ph Decrease}

When As(III) replaced As(V) in the feed, total As concentration in the outlet did not increase, but rather decreased (Figure 2). This result indicated that As(III) at $100 \mathrm{mg}^{-1}{ }^{-1}$ was not inhibitory, and suggested that As(V) reduction was a limiting step in the global As removal process. Then, with a residence time of 3.76 days (90 h), the $\mathrm{pH}$ of the feed solution was decreased from 4.4 to 2, in three steps (day 301 to day 356). This change in feed pH had a positive effect on the As removal efficiency. Arsenic concentration in the outlet decreased down to $1 \mathrm{mg} . \mathrm{l}^{-1}$ (day 360 to day 375). The residence time was further decreased, and the outlet As concentration remained constant between 0 and 1 mg. $\mathrm{l}^{-1}$, as long as the residence time value was not lower than $48 \mathrm{~h}$. Such good As removal efficiency was maintained in these conditions (48 h residence time, $\mathrm{pH} 2$ in the feed) during 35 days (day 412 to day 447).

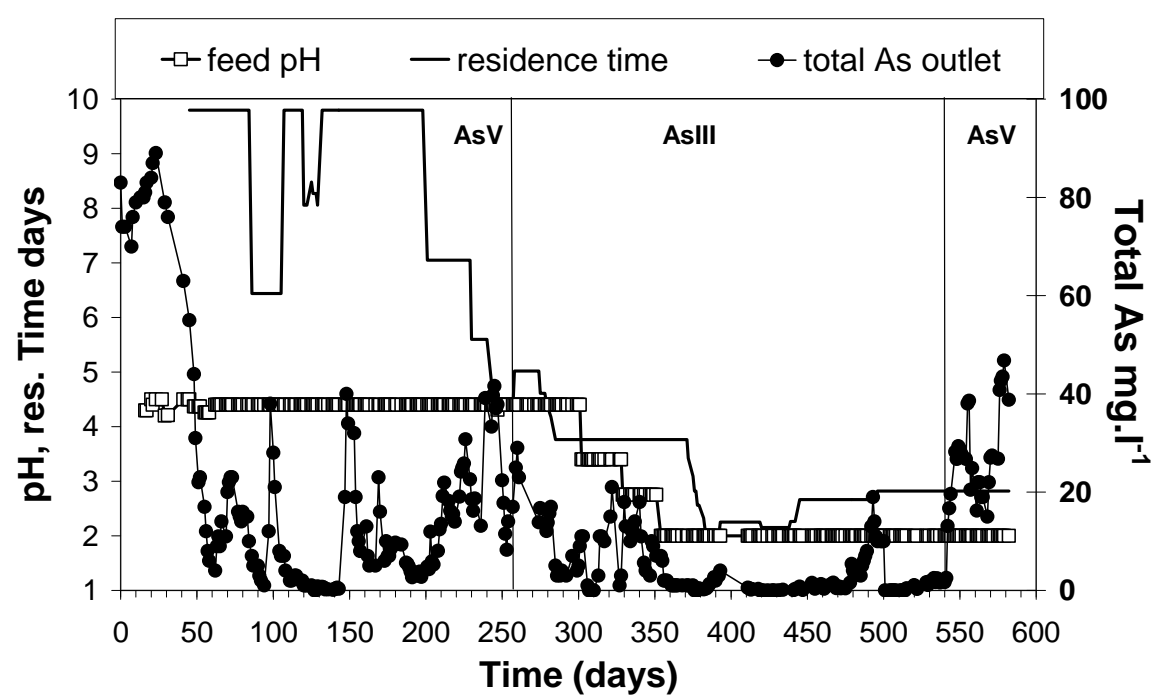

Figure 2. Evolution of As concentration in the outlet of the bioreactor, feed $\mathrm{pH}$ and residence time. As concentration in the feed was $100 \mathrm{mg}^{-1}$.

Then, the As concentration increased in the outlet, suggesting that the system was not in perfect steady state, but in a "pseudo" steady state during this period. As a fact, the outlet $\mathrm{pH}$ progressively decreased from 7.5 to 2.8 , and a yellow colour colonised the column from the bottom to the top. It seemed that the bacterial activity progressively moved into the column, from the bottom to the top. And when it reached the top, some As appeared in the outlet. Each time a slight increase of residence time was applied (days 392, 440, 493), the As concentration decreased in the outlet, and a transient increase of outlet $\mathrm{pH}$ was observed.

From a chemical point of view, the lowest $\mathrm{pH}$ could be applied, the highest $\mathrm{As}_{2} \mathrm{~S}_{3}$ formation rate should be obtained. As a fact, the As removal was very efficient when the feed solution at $\mathrm{pH} 2$ was used, however this $\mathrm{pH}$ did not allow to maintain the bacterial activity in a steady-state. The bacteria could hardly be active at $\mathrm{pH} 2$. The most probable scenario is the following: the bacteria were active into zones of higher $\mathrm{pH}$, and the $\mathrm{H}_{2} \mathrm{~S}$ diffused from these zones to the lower $\mathrm{pH}$ sectors where precipitation occurred.

The global arsenic removal rate was calculated for the whole experiment. The maximum removal rate was close to 2.1 $\mathrm{mg} . \mathrm{l}^{-1} \cdot \mathrm{h}^{-1}$ for As(III), with a feed at $\mathrm{pH}$ 2. When all arsenic in the feed was in the As(V) form, the maximum global removal rate was close to $1.1 \mathrm{mg} \cdot \mathrm{l}^{-1} \cdot \mathrm{h}^{-1}$. In the full-scale application described by Maniatis and Pickett (2005), the As removal rate was $0.25 \mathrm{mg} \cdot \mathrm{l}^{-1} \cdot \mathrm{h}^{-1}$.

\section{Bio-Molecular Monitoring}

CE-SSCP fingerprints of 16S rRNA genes revealed the presence of two main species in the consortium used to inoculate the column (data not shown). 16S rRNA gene library analyses revealed that one of the peaks corresponded to a species of the Gram+ genus Bacillus, being $97 \%$ related to B. senegalensis and B. niacini. A second peak corresponded to a sulphate-reducing strain of the Gram+ genus Desulfosporosinus, its closest relative being Desulfosporosinus Y5 (95\% identity), a strain isolated from polluted lake sediments and able to respire As(V) (Liu et al., 2004). The Bacillus- and Desulfosporosinus-related strains dominated the gene library, as it was the case on CESSCP fingerprints. 
Finally, a third peak corresponded to a sequence only distantly related (95\%) to an environmental sequence not related to any known bacteria.

Molecular monitoring of the bacterial community structure during the column experiment has been performed at the bottom and the top of the column, as well as in the outlet flow (Figure 3). Despite the fact that only two main species had been detected in the inoculum, a complex community has developed in the column after 73 days of operation. These bacteria were certainly present in the inoculum, but at a low density in the batch conditions applied to the culture, which may explain why they were not detected at that time. When looking at the fingerprints obtained from the column bottom (close to the feed), a peak corresponding to the Desulfosporosinus sp. retrieved in the inoculum dominated the profile during more than six months (Day 105 to 300). Then, its ratio decreased to be almost absent at Day 371, after the $\mathrm{pH}$ of the feed has been decreased to 2. The strain of Bacillus initially retrieved in the inoculum was detected from Day 253 towards the end of the monitoring. The corresponding peak ratio increased at Day 328 to the detriment of the Desulfosporosinus peak. At that time and at the end of the monitoring, an unidentified peak dominated the profile.

From days 253 to 328, fingerprints obtained from the top were somewhat similar to that from the bottom, as same peaks were generally detected. However here, another strain of Bacillus, Bacillus sp. 2, was found in low ratios. It is clear that the Desulfosporosinus sp. has found adequate conditions for its development and maintenance in the upper part of the column, being dominant most of the time, especially at Day 371 when it was not detected from the column bottom.

The community structure was different in the outlet flow than at the top of the column. If same peaks were detected, they differed in ratios. The main observation was an inversion at days 253 and 300 of ratios between the Desulfosporosinus sp. peak that dominated at the top and the Bacillus sp. 2 peak being dominant in the outlet. Here, the monitoring has been performed on the liquid coming out from the top of the column, and an effect of exposure to air and the presence of a contaminant biofilm in the tubing can not be ruled out.

Results from the biomolecular population monitoring confirmed the presence of a stable sulphate-reducing population during the course of the experiment. The fact that identical profiles were found at the end of the As(V) period (Day 253) and after almost 50 days of the As(III) period (Day 300) showed that the bacterial community has not been affected by the change of inorganic As species in the feed, although As(III) is usually considered as more toxic than As(V). It was also shown from the column monitoring that As(III) was not inhibitory for the As removal process. After Day 300, when the $\mathrm{pH}$ of the feed was decreased, variations were observed, in particular with a decrease of the ratio of the Desulfosporosinus peak being finally undetected from the column bottom (Day 371). These results are in accordance with the migration of the sulphate-reducing activity from the bottom to the top of the column when the feed $\mathrm{pH}$ was decreased down to $\mathrm{pH}$ 2. Sulphate reducers are usually growing optimally at near neutral $\mathrm{pH}$, and the Desulfosporosinus strain may have been affected by acidic $\mathrm{pH}$ at the column bottom. 


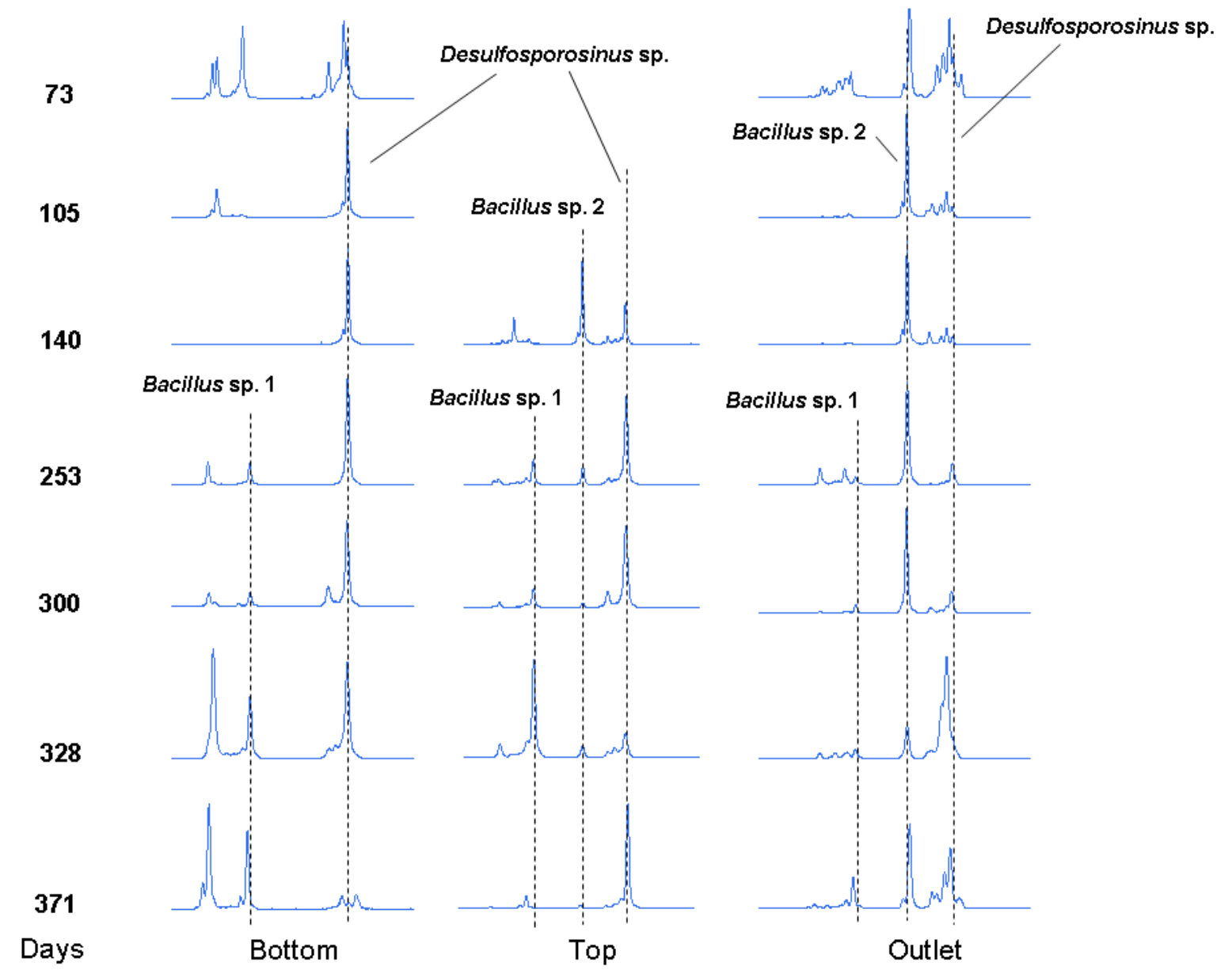

Figure 3. Evolution of CE-SSCP fingerprint of 16S rRNA genes recovered from the column bottom, column top, and the outlet flow. One peak represents one bacterial strain.

\section{Analyse of the Precipitated Solids}

On day 341, the yellow sludge was sampled at the bottom of the column and dried under N2 in order to perform EXAFS studies. EXAFS Fourier transforms (Figure 4) revealed the presence of amorphous precursors of orpiment of nano-size. EXAFS Fourier transforms showed similarities between the biogenic sample "I-As-10 SRB" and the BRGM reference for crystallised "Orpiment BRG” (Figure 4). The EXAFS-derived local structure of As revealed also clearly the presence of amorphous precursors of orpiment of nano-size.

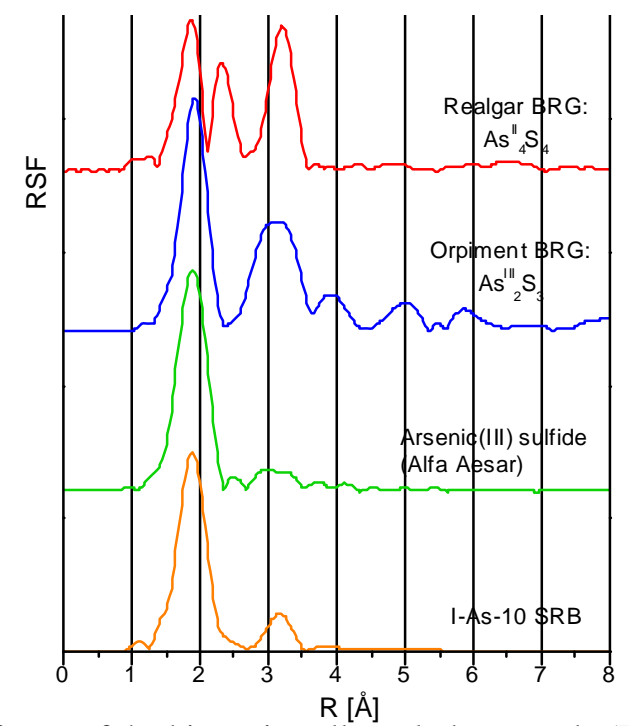

Figure 4. EXAFS Fourier transforms of the biogenic yellow sludge sample (I-As-10 SRB) and of selected references (Realgar BRG, Orpiment BRG, Alfa Aesar) showing the presence of amorphous orpiment 


\section{Final Dismantling of the Bioreactor}

The distribution of bacterial concentration (in the liquid phase and onto the solids) and the $\mathrm{pH}$ inside the bioreactor at the end of the experiment is given in Table 2. Some sectors inside the column were exposed at a pH higher than the inlet and outlet $\mathrm{pH}$. As a fact, during the last days of the experiment, the column was fed at $\mathrm{pH} 2$ and the outlet $\mathrm{pH}$ was 2.9, whereas inside the column, the average $\mathrm{pH}$ was higher than 4 from $10 \mathrm{~cm}$ above the feed to $5 \mathrm{~cm}$ beneath the outlet. The sectors with $\mathrm{pH}$ higher than 4 exhibited the highest bacterial concentrations in the liquid phase (Table 2, in bold). These results suggest that the bacterial activity was concentrated in the 10-to-30 $\mathrm{cm}$ zone above the feed. The solution percolated through the filling material by taking preferential channels, and the dissolved $\mathrm{H}_{2} \mathrm{~S}$ diffused from the zones where sulphate reduction occurred toward these channels, where $\mathrm{As}_{2} \mathrm{~S}_{3}$ precipitation occurred. This scenario would explain the different coloured zones and the low value of outlet $\mathrm{pH}$. The $\mathrm{pH}$ of the solution in the preferential channels remained lower than 3 , while $\mathrm{pH}$ was higher than 4 in the sulphate-reducing zones.

Table2. Bacterial concentrations and pH inside the column at the end of experiment.

\begin{tabular}{|c|c|c|c|}
\hline $\begin{array}{l}\text { Distance from } \\
\text { the feed } \\
\text { injection point }\end{array}$ & $\begin{array}{c}\text { Bacterial } \\
\text { concentration in the } \\
\text { liquid phase } \\
\text { bact.ml }^{-1}\end{array}$ & $\begin{array}{c}\text { Bacterial } \\
\text { concentration onto } \\
\text { pozzolana } \\
\text { bact.g }^{-1}\end{array}$ & pH \\
\hline (feed) $0-5 \mathrm{~cm}$ & $3.6 \times 10^{7}$ & $2.2 \times 10^{7}$ & 2.96 \\
\hline $5-10 \mathrm{~cm}$ & $2.4 \times 10^{7}$ & $4.5 \times 10^{7}$ & 3.64 \\
\hline $10-15 \mathrm{~cm}$ & $7.2 \times 10^{7}$ & $5.5 \times 10^{7}$ & 4.12 \\
\hline $15-20 \mathrm{~cm}$ & $5.2 \times 10^{7}$ & $7.2 \times 10^{7}$ & 4.06 \\
\hline $20-25 \mathrm{~cm}$ & $5.6 \times 10^{7}$ & $3.8 \times 10^{7}$ & 4.29 \\
\hline $25-30 \mathrm{~cm}$ & $6.0 \times 10^{7}$ & $1.0 \times 10^{8}$ & 4.78 \\
\hline $\begin{array}{c}30-35 \mathrm{~cm} \\
\text { (outlet) }\end{array}$ & $1.68 \times 10^{7}$ & $9.3 \times 10^{7}$ & 3.27 \\
\hline
\end{tabular}

The bacterial community structure has also been determined in the liquid phase and onto the solids when the column was finally dismantled. Fingerprints obtained for the 6 sections showed that after 582 days of run, the community was homogenous from the bottom to the top of the column. Fingerprints were dominated by the Bacillus sp. 1 peak and the unidentified peak, the Desulfosporosinus peak being of much lesser importance, especially for the $30-35 \mathrm{~cm}$ section where it was almost absent. The difference in $\mathrm{pH}$ measured on these samples did not affect the overall bacterial colonization. Fingerprints were highly similar for all $5 \mathrm{~mm}$-sections when comparing the liquid phase and the solids, thus showing that monitoring the population from the liquid phase gave an accurate image of the community established as a biofilm on the pouzzolana.

\section{CONCLUSION}

The bio-precipitation of arsenic sulphide would present several advantages, compared to co-precipitation with iron, for the treatment of effluents from mining and metallurgical industries. The volume of waste would be reduced, and the addition of lime and iron would not be necessary. The present experiment showed the feasibility of As removal by precipitation of amorphous orpiment in a bioreactor inoculated with an acido-tolerant sulphate-reducing bacterial consortium. From a chemical point of view, the precipitation should occur optimally in sulphide-limited conditions, between $\mathrm{pH} 2$ and $\mathrm{pH}$ 4.5. These constrains impose a limited sulphate-reducing activity. In theory, the maximum rate of precipitation would be obtained at $\mathrm{pH}$ 2: the lower $\mathrm{pH}$ would be fixed, the higher the sulphate-reducing activity would be tolerated while avoiding the formation of thio-arsenite species. In the present study, the best efficiency, in terms of residual As concentration in the outlet, was obtained with the lowest feed $\mathrm{pH}$, i.e. $\mathrm{pH}$ 2. However, in these conditions, the bacterial activity inside the bioreactor was isolated in higher $\mathrm{pH}$ zones. These "acid-protected" zones produced $\mathrm{H}_{2} \mathrm{~S}$ that diffused toward the low-pH channels where As precipitation occurred. In spite of these limitations, the $\mathrm{As}_{2} \mathrm{~S}_{3}$ biological precipitation rates obtained in the present study are significantly higher than those found in the state-of-theart. For further experiments, it would be interesting to test other filling materials to favor the creation of "protected islands" where the sulphate-reducing activity could be maintained, allowing to decrease the feed $\mathrm{pH}$ and to increase the feed flow-rate. The study of the microorganisms present in the selected inoculum and in the bioreactor showed that complex and diverse populations were able to develop in acidic conditions and in the presence of relatively high As concentrations. Fermentative and sulphate-reducing bacteria were present, however only a sulphate-reducing species belonging to the Desulfosporosinus genus was detected in the column.

\section{REFERENCES}

Adam, K., Battaglia-Brunet, F., Hau, J. M., Morin, D., Papassiopi, N., Tidy, N. E., Pooley, F. (1997) "Bioleaching of refractory gold arsenopyritic concentrate: from batch testwork to cost estimate"., in IMPC 20 - International Mineral Processing Congress 1997 - Aachen - Germany - 21-26/09/1997, H. Hobeltz \& H. von Blottnitz, Vol. 4, 525-535. 
Battaglia-Brunet, F., Dictor, M.-C., Garrido, F., Crouzet, C., Morin, D., Dekeyser, K., Clarens, M., and Baranger, P. (2002) “An As(III)-oxidizing bacterial population: selection, characterization, and performance in reactors." Journal of Applied Microbiology, 93, 656-667.

d'Hugues, P., Joulian, C., Spolaore, P., Michel, C., Garrido, F., and Morin, D. (2008) “Continuous bioleaching of a cobaltiferous pyrite in stirred reactors: population dynamics and EPS production vs. bioleaching performances.” Hydrometallurgy, 94, 34-41.

Kimura, S., Hallberg, K. B., and Johnson, D. B. (2006) "Sulfidogenesis in low pH (3.8-4.2) media by a mixed population of acidophilic bacteria.” Biodegradation, 17(2): 159-167.

Malasarn, D., Saltikov, C.W., Campbell, K.M., Santini, J.M., Hering, J. G., Newman, D. K. (2004) "arrA is a reliable marker for As(V) respiration.” Science 306, 455.

Liu, A., Garcia-Dominguez, E., Rhine, E. D., and Young, L. Y. (2004) “A novel arsenate respiring isolate that can utilize aromatic substrates.“ FEMS Microbiology Ecology, 48: 323-332.

Maniatis, T., and Pickett, T. (2005) "Biological removal of arsenic from tailings pond water at Canadian mine”. Arsenic Metallurgy, Reddy, R. G. and Ramachadran, V. (eds), The Minerals, Metals \& materials Society, 209-214.

Wagner, M., Roger, A.J., Flax, J.L., Brusseau, G.A,. and Stahl D.A. (1998) "Phylogeny of dissimilatory sulfite reductases supports an early origin of sulfate respiration” Applied and Environmental Microbiology, 180, 29752982 .

Wilkin, R., Wallschlager, D., Ford, R.G. (2003) "Speciation of arsenic in sulfidic waters”, Geochemical Transactions, 4, $1-7$.

Zinck, J. M. (1997) “Acid mine drainage sludge in the Canadian mineral industry: Physical, chemical, mineralogical and leaching characteristics”. Fourth International Conference On Acid Rock Drainage, Vancouver, B. C., vol. IV, 1693-1708.

\section{AKNOWLEDGEMENT}

The present study was performed in the framework of the BIOMINE European Integrated project (contract NMP2-CT2005-500329), and co-funded by BRGM (contribution 6183). 